CLINICAL STUDY

\title{
Seasonality of growth response to GH therapy in prepubertal children with idiopathic growth hormone deficiency
}

\author{
C Land, W F Blum ${ }^{1,2}$, A Stabrey and E Schoenau \\ Children's Hospital, University of Cologne, Joseph-Stelzmann-Strasse 9, D-50924 Cologne, Germany, ${ }^{1}$ Children's Hospital, University of Giessen, \\ Giessen, Germany and ${ }^{2}$ Eli Lilly and Company, Bad Homburg, Germany
}

(Correspondence should be addressed to E Schoenau; Email: Eckhard.Schoenau@medizin.uni-koeln.de)

\begin{abstract}
Objective: Longitudinal growth of children exhibits seasonal variation. In both healthy children and in children with growth hormone (GH) deficiency (GHD) receiving $\mathrm{GH}$ therapy, growth rate is maximal during spring and summer. In the present study, we analyzed the growth response to GH therapy in children with GHD as a function of the season when therapy was started.

Subjects and methods: Anthropometric measurements and biochemical analyses of GH secretion status and bone formation were longitudinally assessed in a cohort of 52 prepubertal children with GHD (14 girls, mean age 7.6 years) who were treated with a fixed dose of $\mathrm{GH}(0.025 \mathrm{mg} / \mathrm{kg} / \mathrm{day})$.

Results: Auxological assessments over the 2-year observation period revealed a significantly better growth response to GH therapy in children who started therapy between the spring and summer (group 1) compared with children who started in the autumn or winter (group 2). The difference was largest in the initial 3-month treatment period $(35 \% ; P<0.01)$. The initial better gain in height of group 1 was sustained during the study period. Baseline peak GH levels during stimulation tests and insuin-like growth factor-I levels did not differ between the two groups. However, group 1 had significantly higher bone resorption and formation markers, either at the start or shortly after initiation of $\mathrm{GH}$ treatment. This suggests that children with GHD have higher bone turnover during spring and early summer, irrespective of GH therapy.

Conclusions: In summary, this study suggests that the season of GH initiation is a determinant of the initial growth response to GH replacement in prepubertal children with GHD.
\end{abstract}

European Journal of Endocrinology 152 727-733

\section{Introduction}

Seasonal variability is probably the best-characterised cyclical pattern of human growth (1-3). As early as 1777 , Buffon reported on seasonal variation in growth (4). Subsequent studies have revealed a biphasic pattern of growth in humans as well as in animals, showing that longitudinal growth is fastest in spring and summer and slowest in autumn and winter $(5-16)$. It is assumed that growth regulation is influenced by external factors such as nutrition, light and dark cycle, outdoor temperature and physical activity $(17-20)$. However, the exact cause of seasonality in growth still remains unclear.

The hormonal and biochemical influences underlying the annual biphasic pattern of height velocity are unknown. Diurnal and monthly rhythms in the secretion and urinary excretion of growth hormone
(GH), insulin-like growth factors (IGFs), and their respective binding proteins (IGFBPs) have been described (21-24), but these observations do not satisfactorily explain the changes in height velocity throughout the year. Rudolf et al. found that GHdeficient (GHD) children treated with a fixed standard dose of GH exhibited a similar biphasic growth pattern as healthy children (25). This finding suggests that changes in growth rate during the year may reflect not only differences in GH secretion but also alterations in sensitivity to GH. The aim of the present study was to investigate whether the growth response to GH therapy in children with GHD is affected by the season when treatment is started. We therefore performed anthropometric measurements as well as analyses of biochemical markers of GH secretion status, bone degradation and bone formation in a cohort of prepubertal children with GHD who were treated with GH. 


\section{Patients and methods}

\section{Patients}

Fifty-two prepubertal children with GHD (14 girls, mean age 7.2 years; 38 boys, mean age 7.8 years) from 27 German centers of pediatric endocrinology participated in a longitudinal trial. The cohort was initially recruited and prospectively followed to create a growth prediction model for growth response to GH treatment of children with GHD (26). The diagnosis of GHD was based upon a height velocity (HV) below the 25th percentile for age and sex and a maximal $\mathrm{GH}$ level of less than $10 \mu \mathrm{g} / \mathrm{l}$ in two standard stimulation tests. The tests used were the arginine test (58.8\%; dose $0.5 \mathrm{~g}$ per $\mathrm{kg}$ body weight up to a maximum of $30 \mathrm{~g})$, the insulin tolerance test $(25.5 \%$; dose $0.1-0.05 \mathrm{IU}$ per $\mathrm{kg}$ body weight), the clonidine test (11.8\%; $0.15 \mathrm{mg}$ per $\mathrm{m}^{2}$ body surface area, orally), and the glucagon test $(3.9 \% ; 0.03 \mathrm{mg} / \mathrm{kg}$ body weight, intramuscularly or subcutaneously). To avoid interference due to pubertal growth, only patients who had no clinical signs of puberty and a bone age below 10 years for boys and 9 years for girls were included in the study. Patients with GHD due to a malignancy, chronic illness including inflammatory bowel disease, coeliac disease and eating disorders, and patients with a recognizable clinical syndrome were excluded. Height, weight and HV were converted to standard deviation scores (SDS) using the German reference values reported by Brandt and Reinken (27). Bone age readings were performed by each participating center according to the method of Greulich and Pyle (28). Relative bone age retardation was calculated as bone age minus chronological age divided by chronological age. Body mass index (BMI) was calculated as weight (in $\mathrm{kg}$ ) divided by the square of height (in meters). Weight for height index was given as a percentage, calculated as the quotient of weight and height. Written informed consent was received from the patients' legal representatives and the study was approved by the local ethics review board of each study site.

\section{Study protocol}

The study was conducted as an open-label, non-controlled multicenter trial. Pre-treatment auxological measurements were recorded at least 6 months prior to the start of therapy. Follow-up auxological assessments were carried out after 3, 6, 12 and 24 months of $\mathrm{GH}$ treatment. Height gain during the study periods was expressed as annualized HV (cm/year). The cohort was divided retrospectively into two subgroups: patients who started GH therapy in the months of March to July (group 1) or patients who started therapy between August and February (group 2). This division into subgroups was based on the observations of Thalange et al. who reported that in healthy prepubertal English children, growth starts to decrease in August, reaches a nadir in January, and exhibits a marked spurt from March to July $(15,16)$. Since there are no major climatic and geographic differences between England and Germany (temperate climate, degree of latitude $58^{\circ}-49^{\circ}$ and $55^{\circ}-47.5^{\circ}$ respectively), the same subdivision was used even though it resulted in time intervals of different lengths ( 5 vs 7 months)

\section{Therapy}

None of the patients in this study had previously been treated with GH. All patients received a standard replacement dose of recombinant human GH (Humatrope; $0.023 \mathrm{mg} / \mathrm{kg} /$ day, 7 injections per week) for the entire study period. No other growth-promoting medications were given. Six patients were also treated with thyroid hormones (group 1, $n=4$; group 2, $n=2$ ). One patient (group 1), who suffered from combined pituitary hormone insufficiency and adrenal insufficiency received thyroid hormone, hydrocortisone and antidiuretic hormone. All patients received stable replacement doses during the entire study period.

\section{Biochemical parameters}

To minimize interassay variation, all laboratory analyses were carried out centrally in specialized laboratories. Serum and urine collections were obtained prior to therapy and at month 1,3 , and 6 after initiation of GH treatment. The 24-h urine sample was collected at home using standardized equipment and samples were sent to the attending physician. Serum and urine samples were stored at $-20^{\circ} \mathrm{C}$ until shipment to the laboratories on dry ice. Urinary deoxypyridinoline (DPD) was analyzed in the osteology laboratory of the University Children's Hospital, Cologne, using a commercially available enzyme immunoassay, according to the manufacturer's instructions (IMMULITE Pyrilinks-D, Metra Biosystems Inc., Mountain View, CA, USA). Urinary concentrations of unglycosylated hydroxylysine (HLY) and its glycoside galactosyl-hydroxylysine (GHL) were determined by reversed phase ion-paired high performance liquid chromatography according to the method of Rauch et al. (29). Mean intra-assay coefficients of variation for HLY, GHL and DPD were 2.6\%, 2.4\%, and 5.7\% respectively. Interassay variability was $5.5 \%, 2.5 \%$, and $6.7 \%$ respectively. Daily excretion of DPD, HYL and GHL was expressed relative to daily urinary creatinine excretion (Cr). IGF-I and IGFBP-3 were measured in the endocrinology laboratory of the University Children's Hospital, Giessen. Serum analysis of IGF-I was carried out using an IGFBP-blocked radioimmunoassay in the presence of a large excess of IGF-II (Mediagnost, Tübingen, Germany), as described elsewhere (26). The intra-assay coefficients of variation ranged from $4.1 \%$ 
to $9.4 \%$, the corresponding interassay coefficients of variation ranged from $5.0 \%$ to $8.7 \%$. IGFBP-3 was measured with a specific radioimmunoassay as described by Blum and colleagues $(30,31)$. The intra-assay coefficients of variation ranged from $5.4 \%$ to $8.6 \%$ and the corresponding interassay coefficients of variation were between $8.0 \%$ and $10.0 \%$. GH levels were assessed locally in the various study centers using different commercial assay kits. Serum concentration of osteocalcin was determined using a commercially available enzyme immunoassay, according to the manufacturer's instructions (OSCAtest, Henning Berlin $\mathrm{GmbH}$, Berlin, Germany). Serum concentrations of procollagen type I C-terminal propeptide (PICP) were analyzed using the commercially available radioimmunassay (PICP, Orion Diagnostica, Turku, Finland) according to the manufacturer's instructions.

\section{Statistics}

The auxologic and biochemical variables are shown as means and S.D., or medians and interquartile range (P25 to P75) (Box and Whisker plots). The significance of differences between the treatment groups was either tested with an unpaired two-tailed $t$-test (in the case of normal distribution of both samples) or by the MannWhitney test. A $P$-value $<0.05$ was considered statistically significant. Longitudinal changes of auxological and biochemical data were tested for significance using either a paired test or Wilcoxon test, as appropriate. A composite $\mathrm{HV}$ regression curve was created to show the seasonal trend of 3-month HV and a fourth order polynomial equation was derived to describe the curve.

\section{Results}

\section{Growth response}

Plotting HV during the first 3 months versus the month of start of $\mathrm{GH}$ treatment exhibited a pattern of higher HV during spring and early summer as compared with late summer, autumn and winter (Fig. 1). Based on this pattern, patients were divided into two subgroups, those who began $\mathrm{GH}$ replacement during the months of March through July and those who started during August to February. Baseline characteristics were not different between the two groups (Table 1). $\mathrm{HV}$ was significantly enhanced after initiation of $\mathrm{GH}$ therapy in all patients, although there was a wide range of growth responses.

A seasonal variation of growth response to $\mathrm{GH}$ therapy was demonstrated between the two groups with a significant difference in HV (Table 2). Treatment started in the spring or early summer led to a better growth in the first 3 months of $\mathrm{GH}$ therapy, by $35 \%$ (14.3 vs $10.6 \mathrm{~cm} /$ year; $P<0.01$ ). The difference,

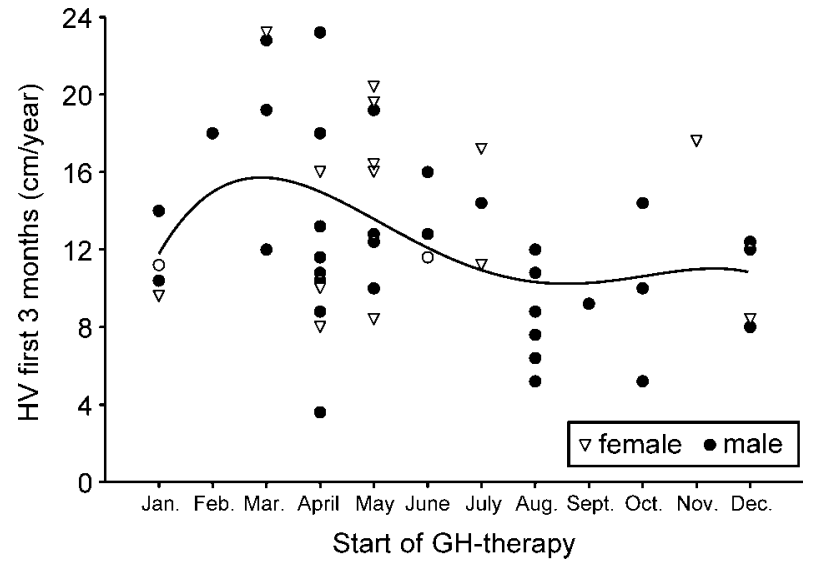

Figure 1 Annualized 3-month height velocity of individual patients versus month of start of $\mathrm{GH}$ therapy. A polynomial regression curve (fourth order equation: $Y=-0.0072 X^{4}+0.23 X^{3}-2.36 X^{2}$ $+8.73 X+5.18$; s.E. $=4.1 ; B=0.18$ ) was fitted to the data.

Table 1 Baseline characteristics of subgroups at start of $\mathrm{GH}$ therapy.

\begin{tabular}{lrrc}
\hline Variable & Group 1 & Group 2 & P-value \\
\hline Age (years) & $7.5(2.9)$ & $8.0(2.9)$ & NS \\
Height (SDS) & $-3.6(1.5)$ & $-3.4(1.0)$ & NS \\
Weight (SDS) & $-3.1(2.2)$ & $-3.2(1.1)$ & NS \\
BMl (kg/m $^{2}$ & $16.0(2.8)$ & $15.2(1.1)$ & NS \\
WHI (\%) & $103.6(19)$ & $102.6(16)$ & NS \\
Bone age retardation (years) & $-2.9(1.4)$ & $-2.7(1.1)$ & NS \\
HV pretreatment (cm/year) & $4.4(1.5)$ & $4.7(1.5)$ & NS \\
Birth weight (kg) & $3.2(0.8)$ & $3.0(0.7)$ & NS \\
Birth length (cm) & $49.9(4.2)$ & $49.0(4.0)$ & NS \\
MPH (SDS) & $-1.2(1.3)$ & $-1.0(1.2)$ & NS \\
\hline
\end{tabular}

Results are given as mean (S.D.). Abbreviations: BMI, body mass index WHI, weight for height index; HV, height velocity; MPH, midparental height; NS, not significant.

Table 2 Longitudinal height changes from baseline during GH therapy and differences between treatment groups.

\begin{tabular}{lcccc}
\hline Variable & $\boldsymbol{n}$ & Group 1 & Group 2 & $\boldsymbol{P}$-value \\
\hline HV 0-3 month (cm/year) & 52 & $14.3(4.9)$ & $10.6(3.5)$ & $<0.01$ \\
Change from baseline (SDS) & 52 & $0.65(0.43)$ & $0.35(0.48)$ & $<0.05$ \\
$\quad$ 3 months & & & & \\
HV 3-6 month (cm/year) & 52 & $10.8(3.5)$ & $10.9(3.7)$ & $\mathrm{NS}$ \\
Change from baseline (SDS) & 52 & $0.84(0.7)$ & $0.48(0.76)$ & $<0.05$ \\
$\quad$ 6 months & & & & \\
HV 6-12 month (cm/year) & 52 & $9.6(2.9)$ & $7.7(2.6)$ & $<0.05$ \\
HV 0-12 month (cm/year) & 52 & $11.1(2.9)$ & $9.3(2.1)$ & $<0.05$ \\
Change from baseline (SDS) & 52 & $1.13(0.62)$ & $0.80(0.49)$ & $<0.05$ \\
$\quad$ 12 months & & & & \\
HV 12-24 month (cm/year) & 23 & $8.5(1.3)$ & $8.1(1.6)$ & $\mathrm{NS}$ \\
HV 0-24 month (cm/year) & 23 & $10.0(1.8)$ & $8.1(0.9)$ & $<0.05$ \\
\hline
\end{tabular}

Results are given as mean and S.D. Abbreviations: HV, height volocity; NS, not significant. 
although smaller, was sustained during the first year, with $\mathrm{HV}$ of 9.6 vs $7.7 \mathrm{~cm} /$ year $(P<0.05)$ during the 6- to 12 -month period and of 11.1 vs $9.3 \mathrm{~cm} /$ year $(P<0.05)$ during the 0 - to 12 -month period. During the second year of GH treatment, the difference in HV between the two groups was not significant ( 8.5 vs $8.1 \mathrm{~cm} /$ year). $\mathrm{HV}$ values during the various time periods are summarized in Fig. 2. Measurements of the change of height during $\mathrm{GH}$ therapy, given in height sDS (Fig. 3), showed the same significant differences, with a better catch-up growth during the first 3 months of GH therapy $(P<0.05)$, in the first 6 months $(P<0.05)$, and during the first year of treatment $(P<0.05)$.

\section{Biochemical parameters}

The results of biochemical markers reflecting $\mathrm{GH}$ secretion status, bone resorption and bone formation at the start and during GH therapy are shown in Table 3. After the start of GH treatment, a significant increase in all biochemical markers was found in our study cohort. While baseline peak $\mathrm{GH}$ levels during stimulation tests, serum alkaline phosphatase (AP) and IGF-I were not statistically different between the treatment groups prior to therapy, urinary DPD excretion was higher in group 1. Urinary GHL and HLY changed in the same significant manner shortly after initiation of GH treatment. During treatment, the increase in serum markers of bone formation (osteocalcin, PICP, AP) and IGFBP-3 was greater in group 1, leading to significant differences between the two groups.

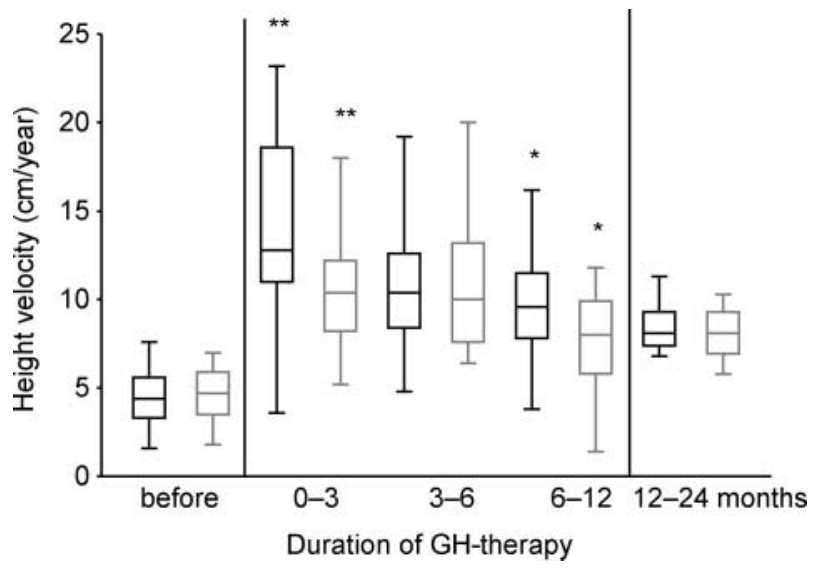

Figure 2 Differences in height velocity between the two subgroups before and after the start of GH therapy. The results are given as Box and Whisker plots which indicate median, interquartile range (P25-P75), and minimum and maximum values. Black boxes, group 1 (GH start March-July); grey boxes, group 2 (GH start August-February). ${ }^{*} P<0.05$ between groups; ${ }^{\star \star} P<0.01$ between groups (Mann-Whitney test).

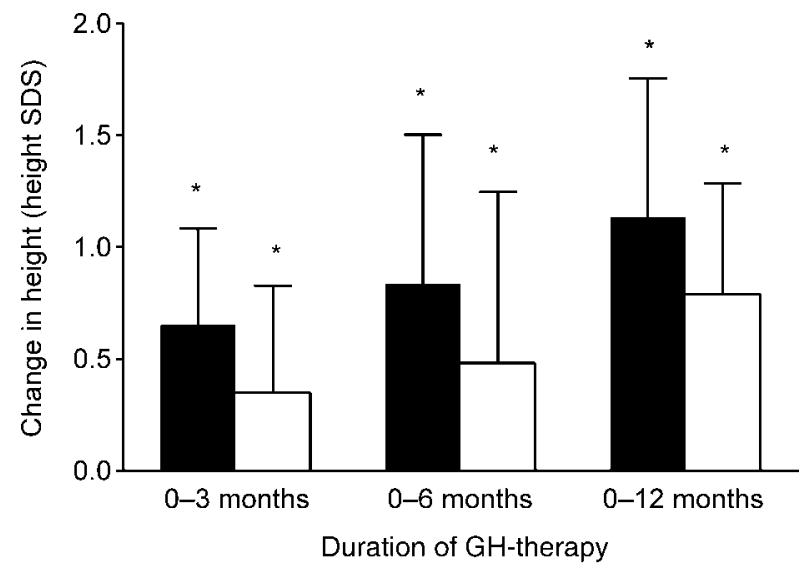

Figure 3 Change of height from baseline during GH treatment differences between subgroups. Results are given as means \pm S.D. Group 1, solid bars (GH start March-July); group 2, open bars (GH start August-February). ${ }^{*} P<0.05$ between groups (MannWhitney test).

\section{Discussion}

The present data suggest that the initial growth response to $\mathrm{GH}$ therapy in prepubertal children with GHD depends on the season when the therapy is started. During GH administration the children with treatment initiation in spring and early summer showed a significantly higher growth rate during the first year. The improvement in growth was largest in the initial 3-month period of treatment. It seems that, despite the lack of statistical differences in HV in the second year of treatment, $\mathrm{GH}$ administration leads to a better total height gain when therapy is started between March and July.

It has been shown that the first-year growth response to GH replacement in children is inversely correlated with age (32), bone age retardation $(32,33)$, height $(34,35)$, nutritional status $(10-12,20)$, weight for height index $(32,35)$ and height velocity before treatment $(34,35)$. Additionally, positive correlations have been shown between $\mathrm{HV}$ and GH dose $(36,37)$, midparental height (37) and frequency of GH injections (38). In our study, the two groups did not differ with respect to these variables, indicating that the reported difference in initial $\mathrm{HV}$ is due to seasonal effects of $\mathrm{GH}$ therapy onset. One may argue that the present difference in gender composition between the two groups could affect overall height gain after 24 months of GH treatment. In our prepubertal study cohort, however, height gain was not statistically different in boys and girls and between the two treatment groups during the two-year observation period. It is likely that this factor may not contribute to the different growth outcome observed between the two groups.

Furthermore, indicators of the GH secretion status such as peak $\mathrm{GH}$ levels in stimulation tests, serum IGF-I and IGFBP-3 levels did not differ between the 
Table 3 Longitudinal changes of serum and urine biochemical data and differences between groups.

\begin{tabular}{|c|c|c|c|c|c|}
\hline Variable & $n$ & At start & 1 month & 3 months & 6 months \\
\hline Stimulated peak $\mathrm{GH}$ level $(\mu \mathrm{g} / \mathrm{l})$ & 52 & $5.5(3.2)$ & - & - & - \\
\hline Group 1 & 31 & $5.4(4.7)$ & - & - & - \\
\hline Group 2 & 21 & $5.6(2.4)$ & - & - & - \\
\hline IGF-I ( $\mu \mathrm{g} / \mathrm{I})$ & 46 & $29(9 / 104)^{\star}$ & $102(69)^{\mathrm{a}}$ & $99(58)^{a}$ & $112(70)^{\mathrm{a}}$ \\
\hline Group 1 & 28 & $21(9 / 127)^{\star}$ & $93(70)$ & $99(62)$ & $106(69)$ \\
\hline Group 2 & 18 & $46(9 / 90)^{*}$ & $118(66)$ & 99 (52) & $124(71)$ \\
\hline IGFBP-3 (mg/l) & 47 & $1.61(1.0)$ & $2.75(0.90)^{\mathrm{a}}$ & $2.82(0.83)^{a}$ & $2.95(1.0)^{\mathrm{a}}$ \\
\hline Group 1 & 28 & $1.43(1.2)$ & 2.60 (0.90)\# & $2.87(0.81)$ & $2.79(0.9)$ \\
\hline Group 2 & 19 & $1.90(0.9)$ & $3.00(0.90)$ & $2.77(771)$ & $3.24(1.0)$ \\
\hline Alkaline phosphatase (U/l) & 49 & $244(66)$ & $298(73)^{a^{\prime}}$ & $361(80)^{a}$ & $352(80)^{a}$ \\
\hline Group 1 & 29 & $245(66)$ & $312(76)$ & $380(77.6)^{f}$ & $367(99)$ \\
\hline Group 2 & 20 & $247(66)$ & $273(64)$ & $331(75.4)$ & $331(91)$ \\
\hline Osteocalcin $(\mu \mathrm{g} / \mathrm{l})$ & 48 & $15.4(5.0)$ & $19.2(3.6)^{\mathrm{a}}$ & $22.4(5.0)^{\mathrm{a}}$ & $21.8(5.6)^{\mathrm{a}}$ \\
\hline Group 1 & 29 & $14.8(4.2)$ & 19.9 (2.9)\# & $23.8(4.1)^{f} \S$ & $23.6(4.0)^{\mathrm{e}} \$$ \\
\hline Group 2 & 19 & $16.3(6.1)$ & $18.1(4.3)$ & $20.3(5.6)$ & $18.9(6.7)$ \\
\hline PICP $(\mu \mathrm{g} / \mathrm{l})$ & 49 & $304(112)$ & $529(295)^{a}$ & $602(285)^{a}$ & $534(266)^{a}$ \\
\hline Group 1 & 29 & $326(119)$ & $597(317)^{f}$ & $650(230)$ & $577(262)$ \\
\hline Group 2 & 20 & $271(93)$ & $418(221)$ & $532(344)$ & $472(265)$ \\
\hline Urine HLY (nmol/mmol Cr) & 50 & $19.1(14.3)$ & $32.9(29.9)^{b}$ & $34.6(32.4)^{b}$ & $28.8(21.9)^{\mathrm{b}}$ \\
\hline Group 1 & 30 & $19.9(14.6)$ & $39.8(35.3)^{f}$ & $39.8(38.8)$ & $29.3(18.9)$ \\
\hline Group 2 & 20 & $17.7(14.2)$ & $21.9(13.0)$ & $26.7(17.8)$ & $27.9(26.6)$ \\
\hline Urine DPD (nmol/mmol Cr) & 50 & $17.3(7.8)$ & $25.5(10.0)^{a}$ & $27.0(11.3)^{a}$ & $25.4(11.4)^{\mathrm{a}}$ \\
\hline Group 1 & 30 & $19.1(8.7)^{f}$ & $29.1(10.6)^{c}$ & $30.2(12.1)^{\mathrm{e}}$ & $29.4(12.8)^{\mathrm{d}}$ \\
\hline Group 2 & 20 & $14.3(4.9)$ & $19.8(5.8)$ & $23.3(7.9)$ & $19.1(3.7)$ \\
\hline Urine $\mathrm{GHL}(\mathrm{nmol} / \mathrm{mmol} \mathrm{Cr})$ & 50 & $41.8(14.3)$ & $60.2(20.2)^{a}$ & $65.7(27.1)^{\mathrm{a}}$ & $60.0(25.7)^{\mathrm{a}}$ \\
\hline Group 1 & 30 & $42.1(13.8)$ & $65.0(23.0)^{f}$ & $70.5(31.9)$ & $65.4(29.3)$ \\
\hline Group 2 & 20 & $41.3(15.4)$ & $53.1(12.6)$ & $58.4(15.9)$ & $51.4(15.8)$ \\
\hline
\end{tabular}

Results are given as mean and S.D. (*Median, P25-P75, Mann-Whitney test).

${ }^{\mathrm{a}} P<0.001$ vs baseline value; ${ }^{\mathrm{b}} P<0.005$ vs baseline value; ${ }^{\mathrm{c}} P<0.001$ vs group $2 ;{ }^{\mathrm{d}} P<0.005$ vs group $2 ;{ }^{\mathrm{e}} P<0.01$ vs group $2 ;{ }^{f} P<0.05$ vs group 2. \# Change from baseline, $P<0.05$ between groups; $\$$ change from baseline, $P<0.005$ between groups; $\S$ change from baseline, $P<0.001$ between groups.

two groups at baseline. During the first six months of GH treatment, the increase in serum IGF-I was larger in group 1, but the differences between the groups did not reach significance. On the other hand, the increase in IGFBP-3 was significantly greater in group 1. These results are in accordance with reports of other authors who showed that initial changes in serum concentrations of IGF-I, IGFBP-3 and AP are positively correlated with growth response during $\mathrm{GH}$ replacement in children with GHD (39). Because changes in IGF-I and IGFBP-3 levels can be considered surrogate markers of GH responsiveness, these findings support the observation of seasonal variation of growth during GH treatment.

It is noteworthy that different markers of bone degradation and bone formation showed significantly higher values prior to (DPD) or shortly after (GHL, HLY, AP, PICP, osteocalcin) initiation of GH in children who started therapy between spring and early summer. It has been shown that the excretion of collagen crosslinks is higher in states of enhanced bone turnover and reflects the rate of collagen degradation associated with bone remodeling during growth $(40,41)$. The excretion of urinary collagen cross-links increases significantly after initiation of $\mathrm{GH}$ treatment in children with GH deficiency and is positively correlated to the degree of early growth response to GH therapy
(40-44). The finding of higher urinary collagen cross-links excretion in group 1 suggests that children with GHD have higher bone turnover during spring and early summer, irrespective of GH therapy. Based on these findings, it may be hypothesized that even baseline growth without $\mathrm{GH}$ replacement in such patients shows a seasonal variation.

As the GH dose in this trial was fixed, the occurrence of a significant seasonal difference in growth response suggests that the regulatory mechanisms behind this phenomenon are not related to differences in $\mathrm{GH}$ exposure, but to GH responsiveness. The latter is supported by the significantly larger increase in serum IGFBP-3 and AP in group 1 in this study and also by the observation that short-term variations in serum IGF-I are positively correlated to short-term changes in longitudinal growth (39). It remains unclear whether the seasonal GH effect occurs only via differences in the responsiveness of the IGF system. However, it is more likely that the growth plate, as the primary site of longitudinal growth, is directly affected by seasonal changes of external and internal growth promoting and growth arresting factors resulting in a biphasic seasonal growth pattern.

In conclusion, these data indicate that a seasonal variation in $\mathrm{GH}$ responsiveness exists in children with GHD including possible alterations of the growth 
plate. The underlying growth modulating mechanisms lead to a biphasic growth pattern showing a peak of height velocity in spring and early summer and a decline in late summer, autumn and winter. However, these results require confirmation in a larger group of individuals before any firm conclusions can be drawn regarding, for instance, the season when GH replacement should be commenced or at what dosage.

\section{Acknowledgements}

The authors are grateful for the endeavors and continuous commitment of the members of the Lilly Growth Response Study Group: Drs Böhles (Frankfurt), Brack (Bonn), Butenandt (München), Eisberg (Minden), Götze (Esslingen), Haverkamp (Bonn), Heinrich (Heidelberg), Hinkel (Dresden), Kiess (Giessen), Lakomek (Göttingen), Leitner (Frankfurt), Mischo (Neunkirchen), Mohnike (Magdeburg), Morlot (Hannover), Mühlenberg (Krefeld), von Petrykowski (Freiburg), Ranke (Tübingen), Sauerbrei (Erfurt), Schnabel (Berlin), von Schnakenburg (Bonn), Tittel (Dresden), Ullrich (Gotha), Vilser (Jena), Voigt (Halle), Wüsthof (Hamburg) and Zabransky (Homburg).

\section{References}

1 Bransby ER. The seasonal growth of children. Medical Officer 194573 149, 157 and 165.

2 Marshall WA. Evaluation of growth rate in height over periods of less than one year. Archives of Diseases in Childhood $1971 \mathbf{4 6}$ 414-420.

3 Falkner F, Tanner JM. Human Growth, vol 2. London: Bailliere Tindall, 1978

4 Buffon G. Oeuvres Completes de Buffon Mises en Ordre des Precedees d'une Notice Historique par M A Richard. Paris: Pourrat Freres, 1833.

5 Reynolds EL \& Sontag LW. Seasonal variations in weight, height and appearance of ossification centers. Journal of Pediatrics 1955 24 524-535.

6 Tanner JM. Education and Physical Growth, 2nd edition. London: Hodder and Stoughton, 1977.

7 Lampl M, Veldhuis JD \& Johnson ML. Saltation and stasis: a model of human growth. Science $1992 \mathbf{2 5 8} 801-803$.

8 Hermanussen M, Geiger-Benoit K, Burmeister J \& Sippell WG. Periodical changes of short term growth velocity ('mini growth spurts') in human growth. Annals of Human Biology 198815 103-109.

9 Hermanussen M, Sippell WG \& Valk IM. Knemometric monitoring of early effects of human growth hormone on leg growth in children with growth hormone deficiency. Lancet 1985 I 1069-1071.

10 Panter-Brick C. Seasonal growth patterns in rural Nepali children. Annals of Human Biology 199724 1-18.

11 Takahashi E. Growth and environmental factors in Japan. Human Biology 196638 112-130.

12 Billewicz WZ. A birth to maturity longitudinal study of heights and weights in two West African (Gambian) villages 19511975. Annals of Human Biology 19829 309-320.

13 Bogin BA. Seasonal pattern in the rate of growth in height of children living in Guatemala. American Journal of Physical Anthropology $197849205-210$.
14 Gelander L, Karlberg J \& Albertsson-Wikland K. Seasonality in lower leg length velocity in prepubertal children. Acta Pediatrica 199483 1249-1254.

15 Thalange NKS, Foster PJ, Gill MS, Price DA \& Clayton PE. Model of normal prepubertal growth. Archives of Diseases in Childhood 1996 75 427-431.

16 Tillmann V, Thalange NKS, Foster PJ, Gill MS, Price DA \& Clayton PE. The relationship between stature, growth, and short-term changes in height and weight in normal prepubertal children. Pediatric Research $1998 \mathbf{4 4} 882-886$.

17 Roemmich JN \& Sinning WE. Sport-seasonal changes in body composition, growth, power and strength of adolescent wrestlers. International Journal of Sports Medicine 199617 92-99.

18 Lee PA. Independence of seasonal variation of growth from temperature change. Growth 198044 54-57.

19 Marshall WA \& Swan AV. Seasonal variation in the growth rates of normal and blind children. Human Biology 197143 502-516.

20 Greco L, Tipo V, Di Donato F \& Mayer M. Pulsatile growth pattern during catch-up growth in childhood coeliac disease. Acta Pediatrica Scandinavica 199483 724-729.

21 Gelander L, Blum WF, Larsson L, Rosberg S \& AlbertssonWikland K. Monthly measurements of insulin-like growth factor I (IGF-I) and IGF-binding protein-3 in healthy prepubertal children: characterization and relationship with growth: the 1-year growth study. Pediatric Research 199945 377-383.

22 Martha PM, Gorman KM, Blizzard RM, Rogol AD \& Veldhuis JD. Endogenous growth hormone secretion and clearance rates in normal boys, as determined by deconvolution analysis: relationship to age, pubertal status and body mass. Journal of Clinical Endocrinology and Metabolism 199274 336-344.

23 Thalange NKS, Gill MS, Gill L, Whatmore AJ, Addison GM, Price DA \& Clayton PE. Infradian rhythms in urinary growth hormone excretion. Journal of Clinical Endocrinology and Metabolism 199681 100-106.

24 Gelander L, Karlberg JPE, Larsson LA, Rosberg S \& AlbertssonWikland K. Overnight urinary growth hormone in normally growing prepubertal children. Hormone Research 199849 8-16.

25 Rudolf MCJ, Zadik Z, Linn S \& Hochberg Z. Seasonal variation in growth during growth hormone therapy. American Journal of Diseases of Children 1991145 769-772.

26 Schoenau E, Westermann F, Rauch F, Stabrey A, Wassmer G, Keller E, Brämswig J \& Blum WF. A new and accurate prediction model for growth response to growth hormone treatment in children with growth hormone deficiency. European Journal of Endocrinology $2001 \mathbf{1 4 4} 13-20$.

27 Brandt I \& Reinken L. The growth rate of healthy children in the first 16 years: Bonn-Dortmund longitudinal developmental study. Klinische Paediatrie 1988200 451-456.

28 Greulich W \& Pyle S. Radiographic Atlas of Skeletal Development of the Hand and Wrist, 2nd edition. Stanford: Stanford University Press, 1959.

29 Rauch F, Schoenau E, Woitge H, Remer T \& Seibel M. Urinary excretion of hydroxypyridinum cross-links of collagen reflects skeletal growth velocity in normal children. Experimental and Clinical Endocrinology 1994102 94-97.

30 Blum WF \& Breier BH. Radioimmunoassays for IGFs and IGFPBs. Growth Regulation 19944 11-19.

31 Blum WF, Ranke MB, Kietzmann K, Gauggel E, Zeisel HJ \& Bierich JR. A specific radioimmunoassay for the growth hormone (GH)-dependent somatomedin-binding protein: its use for diagnosis of GH deficiency. Journal of Clinical Endocrinology and Metabolism $1990701292-1298$.

32 Wit JM, Van't Hof MA, Faber JAJ \& Van den Brande JL. The effect of human growth hormone therapy on skinfold thickness in growth hormone deficient children. European Journal of Pediatrics $1988147588-592$.

33 Preece MA, Tanner JM, Whitehouse RM \& Cameron N. Dose dependency of growth response to human growth hormone in growth hormone deficiency. Journal of Clinical Endocrinology and Metabolism $1976 \mathbf{4 2} 477-483$. 
34 Ranke MB, Lindberg A, Chatelain P, Wilton P, Cutfield W, Albertsson-Wikland K \& Price DA. Derivation and validation of a mathematical model for predicting the response to exogenous recombinant human growth hormone $(\mathrm{GH})$ in prepubertal children with idiopathic GH deficiency. KIGS International Board. Kabi Pharmacia International Growth Study. Journal of Clinical Endocrinology and Metabolism $1999841174-1183$.

35 Wit JM, Faber JAJ \& van den Brande JL. Growth response to human growth hormone treatment in children with partial and total growth hormone deficiency. Acta Pediatrica Scandinavica $198675767-773$

36 Ranke MB. Prediction of response to GH: does it help to individualize therapy? Current Opinion in Endocrinology and Diabetes 19996 93-99.

37 Blethen SL, Baptista J, Kuntze J, Foley T, Lafranchi S \& Johanson A. Adult height in growth hormone $(\mathrm{GH})$-deficient children treated with biosynthetic GH. Journal of Clinical Endocrinology and Metabolism 199782 418-420.

38 Albertsson-Wikland K. The effect of human growth hormone injection frequency on linear growth rate. Acta Pediatrica Scandinavica 1987337 110-116.

39 Kriström B, Jansson C, Rosberg S \& Albertsson-Wikland K. Growth response to growth hormone $(\mathrm{GH})$ treatment relates to serum insulin-like growth factor I (IGF-I) and IGF-binding protein-3 in short children with various GH secretion capacities. Journal of Clinical Endocrinology and Metabolism 199782 2889-2898.

40 Rauch F, Schnabel D, Seibel MJ, Remer T, Stabrey A, Michalk D \& Schoenau E. Urinary excretion of galactosyl-hydroxylysine is a marker of growth in children. Journal of Clinical Endocrinology and Metablism $1995 \mathbf{8 0} 1295-1300$.

41 Rauch F, Georg M, Stabrey A, Neu C, Blum WF, Remer T, Manz F \& Schoenau E. Collagen markers deoxypyridinoline and hydroxylysine glycosides: pediatric reference data and use for growth prediction in growth hormone-deficient children. Clinical Chemistry 200248 315-322.

42 Fujimoto S, Kubo T, Tanaka H, Miura M \& Seino Y. Urinary pyridinoline and deoxypyridinoline in healthy children and in children with growth hormone deficiency. Journal of Clinical Endocrinology and Metabolism $1995 \mathbf{8 0} 1922-1928$.

43 Spagnoli A, Branca F, Spadoni GL, Cianfarani S, Pasquino AM \& Argiro G. Urinary pyridinium collagen cross-links predict growth performance in children with idiopathic short stature and with growth hormone $(\mathrm{GH})$ deficiency treated with GH. Skeletal metabolism during GH treatment. Journal of Clinical Endocrinology and Metabolism 199681 3589-3593.

44 Kanzaki S, Hosoda K, Moriwake T, Tanaka H, Kubo T, Inoue M, Higuc J, Yamaji T \& Seino Y. Serum propeptide and intact molecular osteocalcin in normal children and children with growth hormone $(\mathrm{GH})$ deficiency: a potential marker of bone growth and response to GH therapy. Journal of Clinical Endocrinology and Metabolism 199275 1104-1109.

Received 26 October 2004

Accepted 26 January 2005 